\title{
Assessment of marketing strategies among private dental practitioners in Bengaluru city: A cross-sectional survey
}

\author{
Mayur Nath T. Reddy ${ }^{1}$, Radhika Mitra2*, Radhika Muthukuru ${ }^{3}$ \\ ${ }^{1}$ Professor and HOD, ${ }^{2}$ Post Graduate Student, ${ }^{3}$ Reader, Dept. of Public Health Dentistry, Vydehi Institute of Dental Sciences \\ $\&$ Research Centre, Bengaluru, Karnataka, India \\ *Corresponding Author: Radhika Mitra \\ Email: radhika_mitra1992@yahoo.com
}

\begin{abstract}
Introduction: Dentistry, being one of the healing professions, has a commitment to society that its members will adhere to high ethical standards of conduct. The question on whether Indian dentists should advertise their services is an important issue with significant ethical and professional implications. Dental Council of India (DCI), has also given certain guidelines and regulations on advertising issues. But, studies on dentists' opinion on the issues on advertising for dental professionals in India are very meagre.

Aim: To determine the attitude and practices of marketing strategies among private dental practitioners in Bengaluru.

Materials and Methods: A cross-sectional survey was conducted among the private dental practitioners in Bengaluru city. A total of 220 dentists were selected by simple random sampling technique. A self-structured, pre-tested, closed-ended questionnaire, comprising of 23 questions was self-administered. The survey tool consisted of participant's consent, information on demographic details and questions about their attitudes and opinion on marketing strategies that were followed in their clinical practice and the use of social media as a part of marketing strategy by them. Ethical clearance was obtained from the Institutional Review Board. Data was analysed using SPSS v.20. Descriptive statistics and Chi-square test were carried out to check the significant difference.

Results: Of the 220 practicing dentists, $41.8 \%$ were undergraduates and $55.9 \%$ were postgraduates. A majority of $64.1 \%$ of the dentists were in favor of advertising their services. Years of experience of the practitioners was found to be statistically significant with practicing advertising strategies $(\mathrm{p}=0.000)$ and favoring social media as a marketing tool $(\mathrm{p}=0.003)$. The older age groups were more likely to agree and comply with the government ban on advertising by dentists $(\mathrm{p}=0.000)$.

Conclusion: While Indian culture and law does not regard advertising as ethical, in recent years there has been a change in the attitudes of dental professionals to the issue of advertising. This study concludes that ethics are not strictly followed by dental practitioners in their clinical practice. Only a quarter of them agreed on the issue that advertising may make dentistry seem more like a trade.
\end{abstract}

Keywords: Marketing, Advertising, Dental practitioners, Ethics, Law.

\section{Introduction}

For the health professionals, marketing has traditionally been a controversial issue, and the notion of using advertising to promote a professional's practice is relatively new. ${ }^{1}$ However, advertising by healthcare professionals has increased dramatically during the past decade, and this trend seems likely to continue, although many professionals find themselves ill equipped to handle the dynamics of a changing environment, especially without some form of ongoing marketing plan. $^{2}$

The definition of advertising has always been mystified. The most reasonable definition gives that "Advertising includes those activities by which visual or oral messages are addressed to public for the purposes of informing them and influencing them either to buy merchandise or services or to act or be inclined favorably toward ideas, institutions, or person's features." The purpose of advertising, then, is to sell goods, ideas, or services, with the objective of causing action and attitude change on the part of the consumer. ${ }^{3}$ And, among dentists and other health care professionals, "advertising" focuses on two questions. First, what are the legal issues related to dental advertising in India and other countries? Second, what are the attitudes toward advertising among practicing dentists and how are these attitudes changing in recent times? ${ }^{4}$ Advertising is only one aspect of marketing, and every business owner should be aware of how to market their business, even if they cannot advertise. An advertisement is a paid promotion delivered via the media (print, television, radio), but marketing involves a systematic business plan that takes into consideration the business as a whole, including the ethics and culture of the company. ${ }^{5}$

In most of the countries, advertising by dental professionals has been made legal, with certain guidelines and regulations instilled on them. ${ }^{6,7}$ In India, Dentists (Code of Ethics) Regulations Act, 1976 has 
specified certain rules on advertising by dental practitioners. According to which, any formal announcement in the press by dentists should be limited to advertisements on starting practice, change of type of practice, a change of address, on temporary absence from duty for a prolonged period of time, resumption of practice after a break or after a long time, on moving to another practice, or about the availability of a new equipment or services. Insertion in telephone directories or yellow pages or maintenance of websites of dentists or dental clinics where all information is factual will not be construed as unethical practice. Advertising otherwise is considered unethical as it may lower the dignity and honor bestowed on the profession, and furthermore, patients (and their families) experiencing health problems are often particularly vulnerable to persuasive influences, such as via unprofessional advertising. In 2014, revised Dentists (Code of Ethics) Regulations Act was passed with relaxation given to certain rules like size of the signboard. ${ }^{8,9}$ Despite these rules, a number of practitioners ignore the code of ethics to advertise their services.

The popularity of social media is also rapidly growing worldwide. Due to the remarkable advantages offered in the business area, social media is becoming the most recent marketing phenomena. ${ }^{10}$ In modern societies, most providers of professional services compete for consumers, and dental health care services are no exception. Many social media tools are available for health care professionals which is a cost-efficient way to reach hundreds of prospective new patients who search for a practitioner's services and proficiency. ${ }^{11}$

Hence with this background, since studies on dentists' opinion on the issues of advertising are very meager in India, this study was conducted with an aim to determine the attitude and practices of marketing strategies among private dental practitioners, Bengaluru, India.

\section{Materials and Methods}

A cross- sectional study was carried out from August to September 2019, with the objective, to evaluate the opinion on advertising issues and use of social media as a part of marketing strategy among the Private Dental Practitioners in Bengaluru city. Ethical clearance for the study was obtained from the institutional review board of Vydehi Institute of Dental Sciences and Research Centre, Bengaluru. The purpose and details of the study was explained to the study participants, and a written informed consent was obtained from them.

A pilot study was conducted among 25 private dental practitioners, to check the feasibility and to validate the questionnaire. Face validity of the questionnaire was checked by asking experts to scrutinize the questions, while content validity was checked by ensuring that the questions covered all the areas of practice mapped out by initial objective. Test-retest was used to check the reliability of the questionnaire before the study and internal consistency was assessed by using Cronbach's alpha. Cronbach's alpha value of 0.80 suggested good internal consistency of the questionnaire.

Sample size was scientifically obtained after calculation based on the pilot study with $80 \%$ statistical power, a being $0.05,95 \%$ confidence interval and $5 \%$ margin of error. The final sample size obtained was 216 which was rounded off to a total of 220. Simple random sampling technique using the lottery method was employed for the study for selecting the study participants which included the dental practitioners registered under the Indian Dental Association (IDA)Bengaluru branch.

The inclusion criteria for the study was private dental practitioners registered under IDA- Bengaluru branch running their own private dental clinics. Those dentists who were not willing to participate were excluded. Also, dentists who were academicians, associated with dental institutions and the ones attached with corporate clinics were excluded from the study.

The questionnaires were distributed to the randomly selected 220 private dental practitioners registered under the IDA-Bengaluru branch personally by the investigator and all the questions were explained to avoid any ambiguity. The questionnaire was self-structured, pretested, closed-ended instrument, comprising of 23 questions that consisted of participant's consent, information on demographic details and questions about dentists' attitudes and opinions on advertising, and marketing strategies that are followed in clinical practice. The questions were mainly with categorical answers (apart from the number of years in practice), of which 13 were to assess the attitudes and opinions of dentists on advertising and 10 were to assess the various marketing strategies that are followed by the study participants in their dental clinics. It was in English. The participants were given sufficient time to answer the questionnaire and the questionnaire was collected back on the same day 
or the next day. Those who participated in the pilot study were excluded from the main study. The response rate was $100 \%$.

\section{Statistical analysis}

Statistical analysis was carried out to check the difference in statistical significance using Chi-square test as the data was categorical and p-value was fixed at $0.05(5 \%)$. The statistical software namely SPSS 22, IBM Chicago was used for the analysis of the data and Microsoft word and Excel have been used to generate graphs and tables.

\section{Results}

In the present study out of the 220 study subjects, 123 (55.9\%) were males and $97(44.1 \%)$ were females. In regard to age of the participants, majority were among age groups 31-40 years, representing $40.9 \%$ followed by 41-50 years representing $34.1 \%$ and then $<30$ years, representing $14.5 \%$. Around $92(41.8 \%)$ were with B.D.S qualification and $128(58.2 \%)$ were with M.D.S. Nearly, $29.1 \%$ of the study participants in the present study had > 15 years of experience as dental practitioners and $27.7 \%$ had $0-5$ years of experience [Table 1].

Fig. 1 gives the distribution (\%) of participants based on their belief in the concept of marketing and its association with dentistry. Nearly three quarters of practitioners $(73.2 \%)$ believed in concept of Marketing and $85 \%$ believed that marketing is associated with dentistry. A majority of $64.1 \%$ respondents did not believe that advertising by health professionals was unethical or unprofessional. Most of the dentists, (73.2\%) believed that advertising can benefit a dental practice and more than half $(54.5 \%)$ of the dentists also reported of practicing some sort of advertising strategies in their clinical practice (Fig. 2). Among them, 39.2\% of the dentists created websites for clinic as an advertising strategy followed by $29.2 \%$ who created websites and also used patient testimonials and picture of work as strategy (Fig. 3).

When asked regarding the need for advertising/marketing, $53.2 \%$ of the dentists listed that it is required for all the following- for serving the community by ensuring better quality services, as abundance of dental clinics leads to more competition, as traditional referral systems are no longer effective, for augmenting the income by attracting more patients and for visibility and popularity (Fig. 4). On enquiring about the usage of social media behavior, $54.5 \%$ of the dental practitioners reported of using social media as a marketing tool for their clinical practice whereas $45.5 \%$ did not. Of the participants using, majority (40.8\%) reported of using both Facebook and Google plus followed by $29.2 \%$ and $16.7 \%$ who used Google plus and Facebook alone respectively (Fig. 5). Fig. 6 shows the percentages of dental practitioners, practicing various marketing strategies. It was seen that majority $72.7 \%$ reported of using tagline/logo for their clinic, $65.9 \%$ offered discounts/EMI on treatment payments, $61.4 \%$ reported of using attractive pictures, words, or symbols on signboards and $76.8 \%$ arranged free oral check-ups and camps as their marketing strategy. When asked if they condoned the use of global advertising and approved of dental tourism, it was seen that $63.2 \%$ complied with global advertising and dental tourism and $36.8 \%$ opposed (Fig. 7).

Potential correlations between socio-demographic and professional variables (age, qualification and years of experience) and opinion on advertising and practice of marketing strategies were evaluated using the Chi-square test. When different age groups were cross-tabulated against the responses for various questions, the responses for questions, viz., believing in concept of marketing ( $\mathrm{p}=$ $0.000)$, considering advertising to be unprofessional or unethical $(\mathrm{p}=0.000)$, opinion that advertising can be hazardous turning dentistry into trade $(p=0.000)$ and opinion on Indian government's restriction on advertising $(p=0.000)$ showed statistical significance. It was seen that dentists in younger age group $\leq 41$ years were practicing advertising strategy and using social media as a marketing tool more as compared to the older practitioners $\geq 41$ years $(\mathrm{p}=0.000)$. (Table 2$)$

Statistically significant difference had been found between the practitioners with BDS and MDS as their highest qualification. It was seen that majority of practitioners with highest qualification of BDS, believed in concept of marketing $(\mathrm{p}=0.001)$, its association with dentistry $(p=0.009)$ and also offered more discounts on treatment payments $(\mathrm{p}=0.003)$ as compared to those with highest qualification of MDS (Table 3).

When years of experience was cross-tabulated against the responses for various questions, it was observed that with increase in years of experience there was decrease in the belief in concept of marketing and that marketing is associated with dentistry. There was also a decrease in practice of advertising strategy $(p=$ 
$0.000)$ and the use of social media as a marketing tool among the dental practitioners with increase in years of experience and it was found to be highly statistically significant $(\mathrm{p}=0.003)$. Majority of the practitioners with >
15 years of experience were found to agree on the Indian government's restriction on advertising $(\mathrm{p}=0.000)$ (Table 4).

Table 1: Sociodemographic and professional distribution of the surveyed dentists in private dental clinics in Bengaluru city

\begin{tabular}{|l|c|c|}
\hline \multicolumn{1}{|c|}{ Demographic Variables } & n (220) & Percentages \\
\hline Gender & & \\
Male & 123 & 55.9 \\
Female & 97 & 44.1 \\
\hline Age groups (in years) & 32 & 14.5 \\
$<30$ & 90 & 40.9 \\
$31-40$ & 75 & 34.1 \\
$41-50$ & 23 & 10.5 \\
$>50$ & & \\
\hline Qualification & 92 & 41.8 \\
BDS & 128 & 58.2 \\
MDS & & \\
\hline Years of experience & 61 & 27.7 \\
$0-5$ & 52 & 23.6 \\
$6-10$ & 43 & 19.5 \\
$11-15$ & 64 & 29.1 \\
$>15$ & & \\
\hline
\end{tabular}

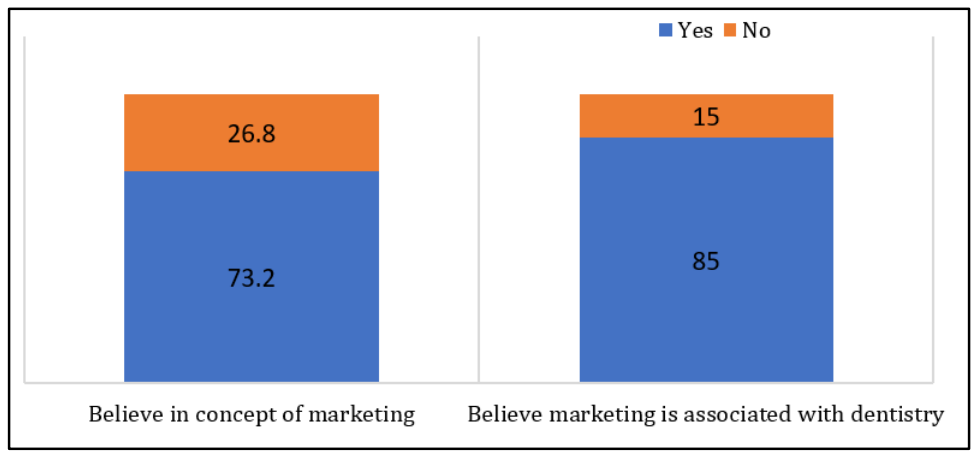

Fig. 1: Distribution (\%) of participants based on their belief in the concept of marketing and its association with dentistry

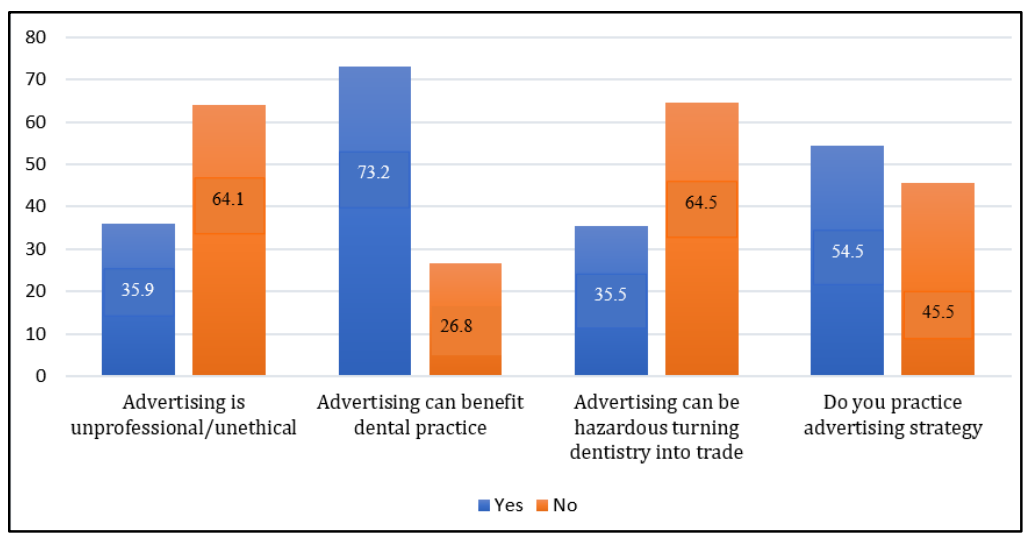

Fig. 2: Percentage of participants based on their response to advertising related questions 


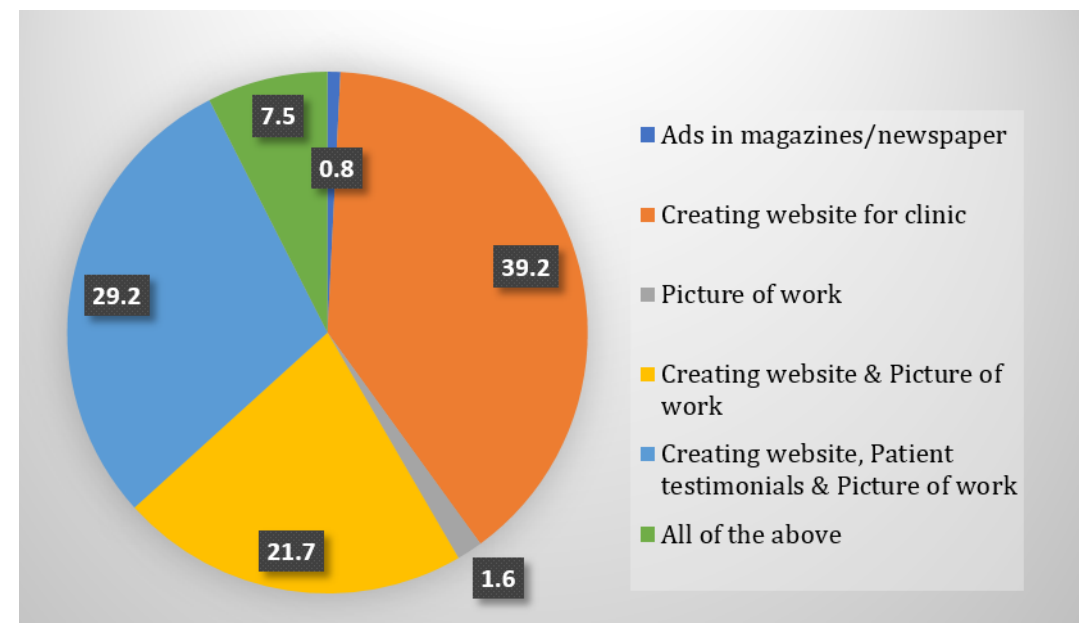

Fig. 3: Distribution (\%) of participants according to preferred type of advertising

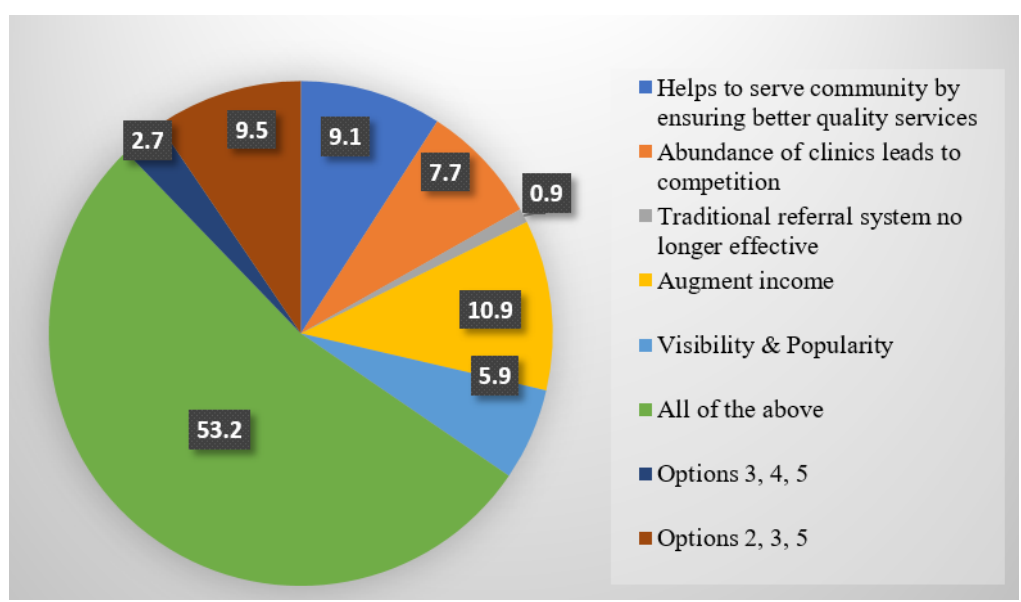

Fig. 4: Percentage of study participants according to the need for advertising/marketing

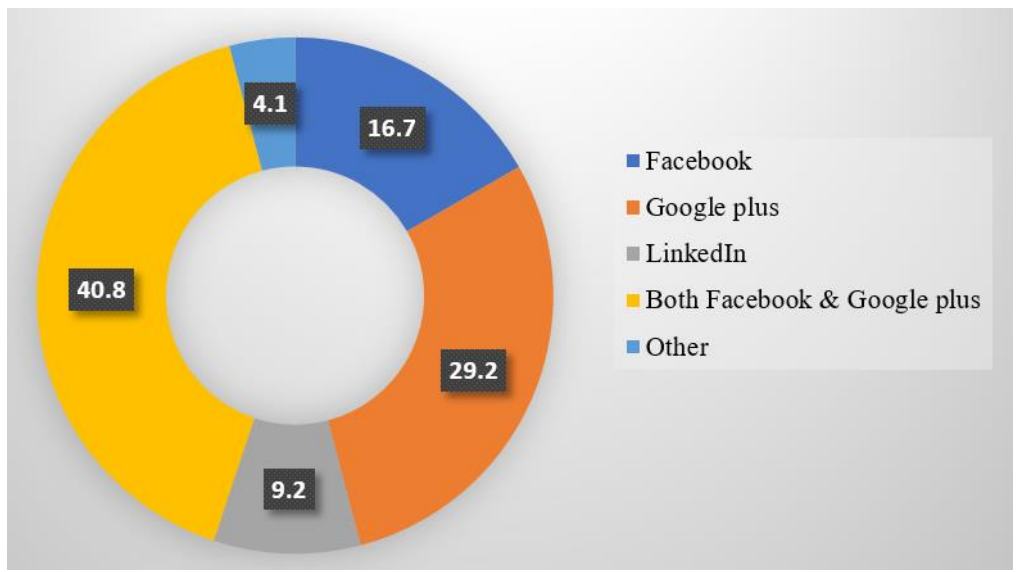

Fig. 5: Distribution (\%) of participants based on their use of social media platforms 


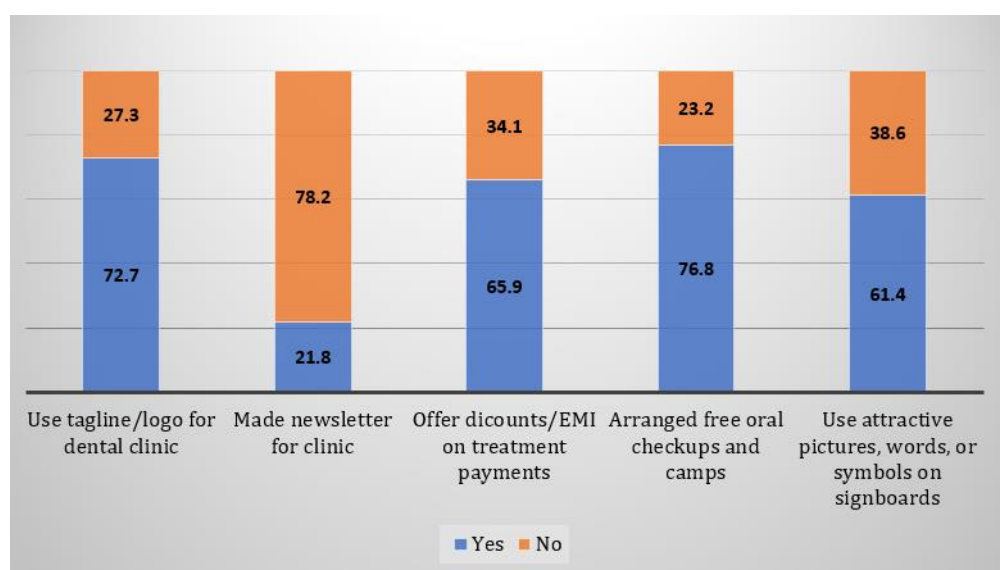

Fig. 6: Percentage of participants practicing various marketing strategies

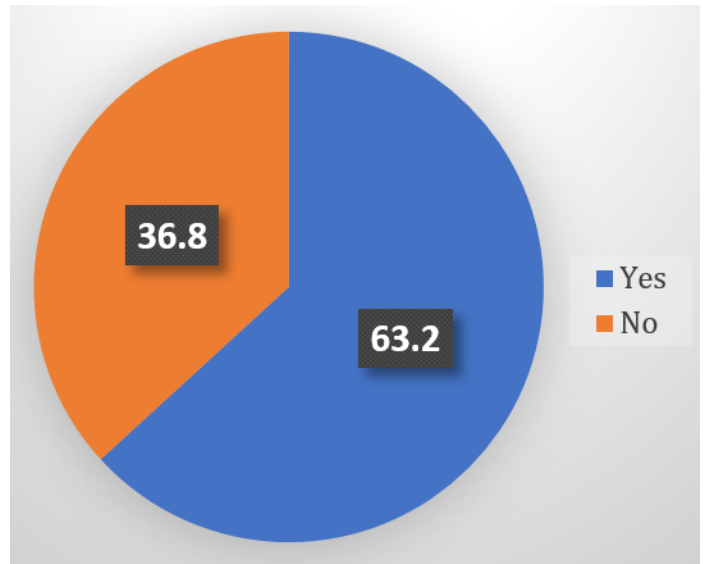

Fig. 7: Percentage of participants based on their opinion on use of global advertising and dental tourism

Table 2: Frequency and percentage distribution of responses given by the subjects of different age groups to various questions on advertising and marketing

\begin{tabular}{|c|c|c|c|c|c|c|}
\hline \multirow[b]{2}{*}{ Questions } & \multicolumn{4}{|c|}{ Age Range (In Years) } & \multirow[b]{2}{*}{$\begin{array}{c}\text { Pearson Chi- } \\
\text { square }\end{array}$} & \multirow[b]{2}{*}{ p- value } \\
\hline & $\begin{array}{c}\leq 30 \\
(n=32)\end{array}$ & $\begin{array}{c}31-40 \\
(n=90)\end{array}$ & $\begin{array}{l}41-50 \\
(n=75)\end{array}$ & $\begin{array}{c}>50 \\
(\mathrm{n}=\mathbf{2 3})\end{array}$ & & \\
\hline $\begin{array}{l}\text { Believe in concept of marketing } \\
\text { Yes } \\
\text { No }\end{array}$ & $\begin{array}{c}30(93.7) \\
02(6.3)\end{array}$ & $\begin{array}{l}81(90.0) \\
09(10.0)\end{array}$ & $\begin{array}{l}43(57.3) \\
32(42.7)\end{array}$ & $\begin{array}{l}07(30.4) \\
16(69.6)\end{array}$ & 50.882 & $0.000 * * *$ \\
\hline $\begin{array}{l}\text { Practice advertising strategy } \\
\text { Yes } \\
\text { No }\end{array}$ & $\begin{array}{l}22(68.7) \\
10(31.3)\end{array}$ & $\begin{array}{l}66(73.3) \\
24(26.7)\end{array}$ & $\begin{array}{l}28(37.3) \\
47(62.7)\end{array}$ & $\begin{array}{l}04(17.4) \\
19(82.6)\end{array}$ & 37.185 & $0.000 * * *$ \\
\hline $\begin{array}{l}\text { Consider advertising unethical } \\
\text { Yes } \\
\text { No }\end{array}$ & $\begin{array}{l}07(21.9) \\
25(78.1)\end{array}$ & $\begin{array}{l}12(13.3) \\
78(36.2)\end{array}$ & $\begin{array}{l}45(60.0) \\
30(40.0)\end{array}$ & $\begin{array}{l}17(73.9) \\
06(26.1)\end{array}$ & 58.999 & $0.000 * * *$ \\
\hline $\begin{array}{llll}\text { Advertising can benefit dental } \\
\text { practice } & & & \\
\text { Yes } & & & \\
\text { No } & & & \\
\end{array}$ & $\begin{array}{l}25(78.1) \\
07(21.9)\end{array}$ & $\begin{array}{l}76 \text { (84.4) } \\
14(15.6)\end{array}$ & $\begin{array}{l}47(62.7) \\
28(37.3)\end{array}$ & $\begin{array}{l}13(56.5) \\
10(43.5)\end{array}$ & 13.693 & $0.003 * *$ \\
\hline $\begin{array}{l}\text { Marketing is relatable only to new } \\
\text { practitioner } \\
\text { Yes } \\
\text { No }\end{array}$ & $\begin{array}{l}07(21.9) \\
25(78.1)\end{array}$ & $\begin{array}{l}22(24.4) \\
68(75.6)\end{array}$ & $\begin{array}{l}44(58.7) \\
31(41.3)\end{array}$ & $\begin{array}{l}13(56.5) \\
10(43.5)\end{array}$ & 27.098 & $0.000 * * *$ \\
\hline
\end{tabular}




\begin{tabular}{|c|c|c|c|c|c|c|}
\hline $\begin{array}{l}\text { Practitioners not marketing are } \\
\text { disadvantaged } \\
\text { Yes } \\
\text { No }\end{array}$ & $\begin{array}{l}19(59.3) \\
13(40.7)\end{array}$ & $\begin{array}{l}52(57.8) \\
38(42.2)\end{array}$ & $\begin{array}{l}24(32.0) \\
51(68.0)\end{array}$ & $\begin{array}{l}03(13.1) \\
20(86.9)\end{array}$ & 23.246 & $0.000 * * *$ \\
\hline $\begin{array}{l}\text { Advertising can be hazardous } \\
\text { turning dentistry into trade } \\
\text { Agree } \\
\text { Disagree }\end{array}$ & $\begin{array}{l}07 \text { (21.9) } \\
25(78.1)\end{array}$ & $\begin{array}{l}14 \text { (15.6) } \\
76(84.4)\end{array}$ & $\begin{array}{l}41(54.7) \\
34(45.3)\end{array}$ & $\begin{array}{l}16 \text { (69.6) } \\
07(30.4)\end{array}$ & 41.943 & $0.000 * * *$ \\
\hline $\begin{array}{l}\text { Use of social media as a marketing } \\
\text { tool } \\
\text { Yes } \\
\text { No }\end{array}$ & $\begin{array}{l}22(68.7) \\
10(31.3)\end{array}$ & $\begin{array}{l}65(72.2) \\
25(27.8)\end{array}$ & $\begin{array}{l}28(37.3) \\
47(62.7)\end{array}$ & $\begin{array}{l}05 \text { (21.7) } \\
18(78.3)\end{array}$ & 32.893 & $0.000 * * *$ \\
\hline $\begin{array}{l}\text { Made newsletter for clinic } \\
\text { Yes } \\
\text { No }\end{array}$ & $\begin{array}{l}06(18.8) \\
26(81.2)\end{array}$ & $\begin{array}{l}29(32.2) \\
61(67.8)\end{array}$ & $\begin{array}{l}10(13.3) \\
65(86.7)\end{array}$ & $\begin{array}{l}03(13.1) \\
20(86.9)\end{array}$ & 10.091 & $0.01 *$ \\
\hline $\begin{array}{l}\text { Use attractive pictures, words or } \\
\text { symbols on signboards } \\
\text { Yes } \\
\text { No }\end{array}$ & $\begin{array}{l}20(62.5) \\
12(37.5)\end{array}$ & $\begin{array}{l}74(82.2) \\
16(17.8)\end{array}$ & $\begin{array}{l}33(44.0) \\
42(56.0)\end{array}$ & $\begin{array}{l}08(34.8) \\
15(65.2)\end{array}$ & 23.246 & $0.000 * * *$ \\
\hline $\begin{array}{l}\text { Indian government's restriction on } \\
\text { advertising } \\
\text { Strongly Agree } \\
\text { Agree } \\
\text { Disagree }\end{array}$ & $\begin{array}{l}04(12.5) \\
07(21.9) \\
21(65.6)\end{array}$ & $\begin{array}{l}08(8.9) \\
09(10.0) \\
73(81.1)\end{array}$ & $\begin{array}{l}15(20.0) \\
29(38.7) \\
31(41.3)\end{array}$ & $\begin{array}{l}06(26.1) \\
14(60.8) \\
03(13.1)\end{array}$ & 55.136 & $0.000 * * *$ \\
\hline
\end{tabular}

Result of Chi-square statistic. ${ }^{*} \mathrm{p} \leq 0.05$ - significant, ${ }^{* *} \mathrm{p}<0.01-$ highly significant $* * * \mathrm{p}<0.001-$ very highly significant

Table 3: Frequency and percentage distribution of responses given by the subjects of different qualification to various questions on advertising and marketing

\begin{tabular}{|c|c|c|c|c|}
\hline \multirow[b]{2}{*}{ Questions } & \multicolumn{2}{|c|}{ Qualification } & \multirow[b]{2}{*}{$\begin{array}{l}\text { Pearson } \\
\text { Chi-square }\end{array}$} & \multirow[b]{2}{*}{ p- value } \\
\hline & $\begin{array}{c}\text { BDS } \\
(n=92)\end{array}$ & $\begin{array}{c}\text { MDS } \\
(\mathrm{n}=128)\end{array}$ & & \\
\hline $\begin{array}{l}\text { Believe in concept of marketing } \\
\text { Yes } \\
\text { No }\end{array}$ & $\begin{array}{l}78(84.8) \\
14(15.2)\end{array}$ & $\begin{array}{l}83(64.8) \\
45(35.2)\end{array}$ & 10.843 & 0.001 ** \\
\hline $\begin{array}{l}\text { Believe marketing is associated with dentistry } \\
\text { Yes } \\
\text { No }\end{array}$ & $\begin{array}{c}85(92.4) \\
07(7.6)\end{array}$ & $\begin{array}{c}102(79.7) \\
26(20.3)\end{array}$ & 6.775 & $0.009 * *$ \\
\hline $\begin{array}{l}\text { Consider advertising unethical } \\
\text { Yes } \\
\text { No }\end{array}$ & $\begin{array}{l}25(27.2) \\
67(72.8)\end{array}$ & $\begin{array}{l}54(42.2) \\
74(57.8)\end{array}$ & 5.243 & $0.02^{*}$ \\
\hline $\begin{array}{l}\text { Practitioners not marketing are disadvantaged } \\
\text { Yes } \\
\text { No }\end{array}$ & $\begin{array}{l}48(52.2) \\
44(47.8)\end{array}$ & $\begin{array}{l}50(39.1) \\
78(60.9)\end{array}$ & 3.725 & $0.05^{*}$ \\
\hline $\begin{array}{l}\text { Advertising can be hazardous turning dentistry into trade } \\
\text { Agree } \\
\text { Disagree }\end{array}$ & $\begin{array}{l}24(26.1) \\
68(73.9) \\
\end{array}$ & $\begin{array}{l}54(42.2) \\
74(57.8) \\
\end{array}$ & 6.063 & $0.01 *$ \\
\hline $\begin{array}{l}\text { Offer discounts/Mis on treatment payments } \\
\text { Yes } \\
\text { No }\end{array}$ & $\begin{array}{l}71(77.2) \\
21(22.8)\end{array}$ & $\begin{array}{l}74(57.8) \\
54(42.2)\end{array}$ & 8.930 & 0.003 ** \\
\hline
\end{tabular}

Result of Chi-square statistic. ${ }^{*} \mathrm{p} \leq 0.05$ - significant, ${ }^{* *} \mathrm{p}<0.01-$ highly significant 
Table 4: Frequency and percentage distribution of responses given by the subjects of different years of experience to various questions on advertising and marketing

\begin{tabular}{|c|c|c|c|c|c|c|}
\hline \multirow{2}{*}{ Questions } & \multicolumn{4}{|c|}{ Years of Experience } & \multirow{2}{*}{$\begin{array}{c}\text { Pearson } \\
\text { Chi-square }\end{array}$} & \multirow{2}{*}{ p- value } \\
\hline & $\begin{array}{c}0-5 \\
(n=61)\end{array}$ & $\begin{array}{l}6-10 \\
(n=52)\end{array}$ & $\begin{array}{l}11-15 \\
(n=43)\end{array}$ & $\begin{array}{c}>15 \\
(n=64)\end{array}$ & & \\
\hline $\begin{array}{l}\text { Believe in concept of marketing } \\
\text { Yes } \\
\text { No }\end{array}$ & $\begin{array}{c}57(93.4) \\
04(6.6)\end{array}$ & $\begin{array}{l}46(88.5) \\
06(11.5)\end{array}$ & $\begin{array}{l}33(76.7) \\
10(23.3)\end{array}$ & $\begin{array}{l}25(39.1) \\
39(60.9)\end{array}$ & 57.185 & $0.000 * * *$ \\
\hline $\begin{array}{l}\text { Believe marketing is associated } \\
\text { with dentistry } \\
\text { Yes } \\
\text { No }\end{array}$ & $\begin{array}{c}57(93.4) \\
04(6.6)\end{array}$ & $\begin{array}{c}49(94.2) \\
03(5.8)\end{array}$ & $\begin{array}{c}39(90.7) \\
04(9.3)\end{array}$ & $\begin{array}{l}42(65.6) \\
22(34.4)\end{array}$ & 26.823 & $0.000 * * *$ \\
\hline $\begin{array}{l}\text { Practice advertising strategy } \\
\text { Yes } \\
\text { No }\end{array}$ & $\begin{array}{l}47 \text { (77.1) } \\
14(22.9)\end{array}$ & $\begin{array}{l}38(73.1) \\
14(26.9)\end{array}$ & $\begin{array}{l}22(51.2) \\
21(48.8)\end{array}$ & $\begin{array}{l}13(20.3) \\
51(79.7)\end{array}$ & 50.111 & $0.000 * * *$ \\
\hline $\begin{array}{l}\text { Consider advertising unethical } \\
\text { Yes } \\
\text { No }\end{array}$ & $\begin{array}{l}07(11.5) \\
54(88.5)\end{array}$ & $\begin{array}{l}08(15.4) \\
44(84.6)\end{array}$ & $\begin{array}{l}17(39.5) \\
26(60.5)\end{array}$ & $\begin{array}{l}47(73.4) \\
17(26.6)\end{array}$ & 64.752 & $0.000 * * *$ \\
\hline $\begin{array}{llll}\text { Advertising can benefit dental } \\
\text { practice } & & & \\
\text { Yes } & & & \\
\text { No } & & & \\
\end{array}$ & $\begin{array}{l}49(80.3) \\
12(19.4)\end{array}$ & $\begin{array}{l}45 \text { (86.5) } \\
07(13.5)\end{array}$ & $\begin{array}{l}28(65.1) \\
15(34.9)\end{array}$ & $\begin{array}{l}39(60.9) \\
25(39.1)\end{array}$ & 12.628 & $0.006^{* *}$ \\
\hline $\begin{array}{l}\text { Marketing is relatable only to new } \\
\text { practitioner } \\
\text { Yes } \\
\text { No }\end{array}$ & $\begin{array}{l}19(31.1) \\
42(68.9)\end{array}$ & $\begin{array}{l}10(19.2) \\
42(80.8)\end{array}$ & $\begin{array}{l}15(34.9) \\
28(65.1)\end{array}$ & $\begin{array}{l}42(65.6) \\
22(34.4)\end{array}$ & 29.475 & $0.000 * * *$ \\
\hline $\begin{array}{l}\text { Practitioners not marketing are } \\
\text { disadvantaged } \\
\text { Yes } \\
\text { No }\end{array}$ & $\begin{array}{l}33(54.1) \\
28(45.9)\end{array}$ & $\begin{array}{l}35(67.3) \\
17(32.7)\end{array}$ & $\begin{array}{l}17(39.5) \\
26(60.5)\end{array}$ & $\begin{array}{l}13(20.3) \\
51(79.7)\end{array}$ & 28.812 & $0.000 * * *$ \\
\hline $\begin{array}{l}\text { Use of social media as a marketing } \\
\text { tool } \\
\text { Yes } \\
\text { No }\end{array}$ & $\begin{array}{l}47(77.1) \\
14(22.9) \\
\end{array}$ & $\begin{array}{l}36(69.2) \\
16(30.8) \\
\end{array}$ & $\begin{array}{l}23(53.5) \\
20(46.5) \\
\end{array}$ & $\begin{array}{r}14(21.9) \\
50(78.1) \\
\end{array}$ & 44.554 & $0.003 * *$ \\
\hline $\begin{array}{l}\text { Made newsletter for clinic } \\
\text { Yes } \\
\text { No }\end{array}$ & $\begin{array}{l}18(29.5) \\
43(70.5)\end{array}$ & $\begin{array}{l}17(32.7) \\
35(67.3)\end{array}$ & $\begin{array}{l}07(16.3) \\
36(83.7)\end{array}$ & $\begin{array}{c}06(9.4) \\
58(90.6)\end{array}$ & 12.302 & $0.006 * *$ \\
\hline $\begin{array}{l}\text { Indian government's restriction on } \\
\text { advertising } \\
\text { Strongly Agree } \\
\text { Agree } \\
\text { Disagree } \\
\text { Strongly disagree }\end{array}$ & $\begin{array}{c}06(9.8) \\
09(14.8) \\
46(75.4) \\
0\end{array}$ & $\begin{array}{c}06(11.5) \\
04(7.7) \\
42(80.8) \\
0\end{array}$ & $\begin{array}{c}02(4.6) \\
14(32.6) \\
27(62.8) \\
0\end{array}$ & $\begin{array}{c}19(29.7) \\
32(50.0) \\
13(20.3) \\
0\end{array}$ & 63.793 & $0.000 * * *$ \\
\hline
\end{tabular}

Result of Chi-square statistic. ${ }^{*} \mathrm{p} \leq 0.05-$ significant, ${ }^{* *} \mathrm{p}<0.01-$ highly significant $* * * \mathrm{p}<0.001-$ very highly significant

\section{Discussion}

In modern societies, most providers of professional services compete for consumers, and dental health care services are no exception. ${ }^{12}$ Dentistry is one of the important health care profession. Nowadays, the dental health care is delivered majority by the private practitioners all around the globe. ${ }^{13}$ In order to maintain a viable practice, general dental practitioners have to be astute managers, using their business skills and acumen to survive. However, research suggests that most of the 
managerial skills dentists' use appear to have been learnt experientially. ${ }^{14}$ Marketing is not synonymous with trickery. Instead, it is nothing more than influencing choice by demonstrating the real value of a particular product or service - in this case, health care. ${ }^{15}$

The revised Dentists (code of ethics) Act, 2014 also gives that: “... A dentist or a group of dentists may advertise provided that they maintain decorum, keeping in mind the high moral obligations and the value that the society places on the important nature of their work and the moral character and integrity expected of them." 8 Accordingly, in the present study, more than half of the respondents $(64.1 \%)$ were in favor of advertising by dental professionals. This was in accordance to study done by Dabale RA et al. ${ }^{5} 2011$ where $56.02 \%$ were in favour of advertising by dental professionals in India. Nonetheless, there were many who still considered advertising by health care professionals to be unethical.

Around $39.2 \%$ of the participants thought that only creating a website for the clinic can largely benefit dental practice, followed by $29.4 \%$ who thought that creating website for dental clinic, along with patient testimonials and picture of their own work together, can benefit their practice. Well-designed websites may help dental practitioners accomplish many of the things essential to building a practice. Websites may streamline administrative tasks, allowing for better patient follow-up and higher patient satisfaction. ${ }^{16}$ On the other hand, many believed along with website, the realism of patients' testimonials and showcasing one's clinical skills, together can be more trustworthy to the clientele/patients. This finding was in contrast to the study done by Nayak PP et al. ${ }^{4} 2016$ where $29 \%$ of the dentists thought that patient's testimonials alone can largely benefit dental practice followed by picture of work (27\%) as compared to creating websites (19\%).

More than half $(54.5 \%)$ of the dentists reported of practicing advertising strategy at their clinic which was in contrast to study done by Shukla H et.al ${ }^{17} 2019$ where $60 \%$ did not practice any advertising strategy. Significant results were observed with dental practitioners practicing for more than 15 years $(\mathrm{p}=0.000)$ wherein no marketing strategy was used. This may be because since decades, dentists relied almost exclusively on reputation and word-of-mouth marketing to help them build their practice. ${ }^{17}$ In today's world of web connectivity, there is a need for improving visibility of dental practice through this media as well. But, the DCI guidelines on
Internet/online advertising by dental professionals are still a bit hazy. ${ }^{4}$ The dentists who were using social media as a marketing tool were $54.5 \%$ in the present study. This result was similar to the findings of Hamasha AAH et al. ${ }^{18} 2019$ (62\%) and in contrast to study done by Snyman L et al. ${ }^{19} 2014$ where only $13.2 \%$ of the dentists were using social media as a marketing tool. It was also seen that the use of social media as a marketing tool among the practitioners was decreasing with increase in age and years of experience and was found to be statistically significant $(p=0.000$ and $p=0.003$ ). This can be attributed to the fact that without advertising, young dental practitioners with less years of experience who have just started their practice might find it difficult to get patients since patients will never know of their existence, skills, and expertise. So, they advertise to increase the visibility of their practice.

This study showed that dentist population with years of experience $<15$ years opined that marketing is not relatable only for newer practitioner as compared to those with more years of experience $(\mathrm{p}=0.000)$. This may be because crowding of dentists in metropolitan cities have led to unhealthy competition and commercialization. ${ }^{17}$ $55.5 \%$ of participants in this study said that dental practitioners who do not advertise are not seen as inferior or are disadvantaged, as many believed that good work and dedication by dentists are sufficient to advance their practice. This was in comparison to Nayak PP et al. ${ }^{4}$ 2016 and Shukla H et.al 2019 where $62 \%$ and $58 \%$ were of same opinion respectively. This shows that most of them believed that advertisement is helpful, but not an obligation that ought to be done "... to indulge in surrogate advertisements in the garb of educating the public through TV programs, magazines or periodicals. ${ }^{8}$

When asked on their opinion on using attractive pictures, wordings, or symbol other than name, qualification, and address on signboards, a significant minority (38.6\%) of dentists agreed. This was way lesser than a study conducted by Sabarinath and Sivapathasundharam ${ }^{20}$ 2011, where a majority of the dental practitioners (68\%) used disproportionately large signs or pictures or symbols in their signboards. This practice by dentists, points to the fact that, in the presentday digital banner era, simple signboards of a dental clinic may become camouflaged near the more colorful and glamorous embellishments of present-day store/establishment. Hence, there is need for the DCI to relax this regulation. ${ }^{4} \mathrm{~A}$ memorable distinctive logo that 
reflects the ideals of a practice is a symbol that patients find easy to remember when thinking about the practice. ${ }^{16}$ In this study $72.7 \%$ of the participants reported of using a logo/tagline for their dental clinic. This was in contrast to Shukla H et.al ${ }^{17} 2019$ where $30 \%$ reported of having a tagline/logo for clinic.

A majority $(63.2 \%)$ of practitioners agreed with the use of global advertising and dental tourism. Since India has an abundance of qualified and skilled doctors who can provide state-of-the-art medical and dental care at a fraction of the cost which doctors in the West charge, there is a tremendous scope to export our medical and dental services. ${ }^{4}$ This finding was in comparison to, but lesser than in the study by Nayak PP et al. ${ }^{4} 2016$ where $81 \%$ agreed with the use of global advertising and dental tourism. If we learn to advertise Indian medical services worldwide effectively, we will be able to attract patients from all over the world, and these services can become a big foreign exchange earner for India.

Considering the changes that take place in a person's social and personal life, the 10 years age range seemed appropriate. However, as only few participants were present in certain age groups, the results should not be interpreted solely based on percentages, but frequencies should also be considered. The advantage of using a questionnaire as a data collecting method is the possibility of collecting a lot of data from a large number of respondents relatively quickly and inexpensively. One more limitation could be that the responses might not have accurately reflected the marketing strategies being practiced, as, it was given by the practitioners and used no methods for assessment of their practices that was used in reality. Furthermore, the results of this study cannot be generalized for all the dental practitioners (especially practicing in the rural area) as it was conducted in Bengaluru city which is the urban techno park.

Dentists, especially the young budding professionals, need to be educated on the do's and don'ts regarding marketing strategies in their BDS curriculum as well as continue doing so via professional development programs and association meetings. The applicability of the laws and conformity of the dentists to the laws can only be possible with a strict monitoring and penalties. The regulatory bodies like DCI and respective state dental councils should also consider about the revision/modification of certain code of ethics.

\section{Conclusion}

While Indian culture and law does not regard advertising as ethical, in recent years there has been a change in the attitudes of dental professionals to the issue of advertising. In spite of the ban on advertising by dentists, there are some who are continuing to use some kind of advertising to promote their services. Nearly three quarters of practitioners agreed that there is a need for some form of advertising. Proportion of dentists agreeing with advertising decreased with age. This may be a reflection of industry competition, a drop in ethical standards, or a greater familiarity with the world of advertising and media among younger age groups.

The rise of new technologies and media is another challenge, but the ethical issues remain the same. Dentists can no longer be oblivious to the fact that the Internet and social media outlets have become integral parts of the everyday lives of most people. Consideration by practitioners to include social media marketing as part of the integrated marketing strategy of the practice, can therefore make sense. Hence, there is a need to advertise, but it must be in terms of the ethical rules of conduct and standards governing the profession and provided they do not bring any dishonor to the profession.

\section{Source of funding}

None.

\section{Conflict of interest}

None.

\section{References}

1. Moser HR. How consumers view dental advertising: An empirical analysis. J Med Marketing. 2008;8(3):229-40.

2. Rizzo JA, Zeckhauser RJ. Advertising and the Price, Quantity, and Quality of Primary Care Physician Services. J Human Res 1992;27(3):381-421.

3. Stock F. Professional Advertising. Am J Public Health 1978;68(12):1207-9.

4. Nayak PP, Raju VK, Kshetrimayum N, Ramesh L, Nayak SS et al. Dentists' Outlook on Advertising in their Line of Work in Bengaluru, India: A Cross-sectional Study. World J Dent 2016;7(3):141-5.

5. Dable RA, Prasanth MA, Singh SB, Nazirkar GS. Is Advertising by Dental Professionals Having a Negative Impact on Consumers?: The Perspectives of Indian Consumers. Drug Healthc Patient Saf 2011;3:93-8.

6. McGuigan PJ, Eisner AB. Marketing the dental practice Eight steps toward success. J Am Dent Assoc 2006;137(10):1426-33. 
7. Principles of Ethics Code of Professional Conduct; November 2018. Available from:

https://www.ada.org/en/about-the-ada/principles-of-ethicscode-of-professional-conduct

8. Code of Ethics. Available from: https://www.ida.org.in/AboutUs/Details/Code-of-Ethics

9. Ahuja BS. The Revised Code of Dental Ethics. World J Adv Sci Res 2019;2(3):1-38.

10. Kirtiş AK, Karahan F. To Be or Not to Be in Social Media Arena as the Most Cost-Efficient Marketing Strategy after the Global Recession. Procedia Soc Behav Sci 2011;24:260-8.

11. Ajwa N, Al Mohsen S, Kuwail A, Al Osaif E. The Impact of Using Social Media Networks on Dental Treatment Marketing in Saudi Arabia: The Practitioners and Patient's Perspectives. J Oral Health Dent 2018;2(3):1-10.

12. Edwards DT, Shroff B, Lindauer SJ, Fowler CE, Tufekci E. Media Advertising Effects on Consumer Perception of Orthodontic Treatment Quality. Angle Orthod 2008;78(5):771-7.

13. Das M, Pradhan D, Sharma L, Sinha KP, Mohanty S. An Insight to Dental Practice Management: A Literature Review. Int J Oral Health Med Res 2018;5(1):54-6.

14. Ashford R, Blinkhorn AS. Marketing dental care to the reluctant patient. Br Dent J 1999;186(9):436-41.
15. Giovino JM. You Should See My Doctor: Cost-Effective Marketing Ideas for Your Practice. Fam Pract Manag 2002:33-6.

16. Clarkson E, Bhatia S. Management and Marketing for the General Practice Dental Office. Dent Clin North Am 2008;52(3):495-505.

17. Shukla H, Chandak S, Rojekar N, Bhattad D. MID [Marketing in Dentistry]: A Cross Sectional Study. Int J Health Sci Res 2019;9(3):128-36.

18. A-H Hamasha A, Alghofaili N, Obaid A, Alhamdan M, Alotaibi A et al. Social Media Utilization among Dental Practitioner in Riyadh, Saudi Arabia. Open Dent J 2013;13:101-6.

19. Snyman L, Visser JH. The adoption of social media and social media marketing by dentists in South Africa. South Afr Dent J 2014;69(6):258-64.

20. Sabarinath B, Sivapathasundharam B. Ethics in dentistry. $J$ Educ Ethics Dent 2011;1:24-7.

How to cite this article: Reddy MNT, Mitra R, Muthukuru R. Assessment of marketing strategies among private dental practitioners in Bengaluru city: A crosssectional survey. Int Dent J Student Res 2019;7(4):92-102. 